\title{
Influencing the adoption of microgeneration technologies using the theory of planned behaviour
}

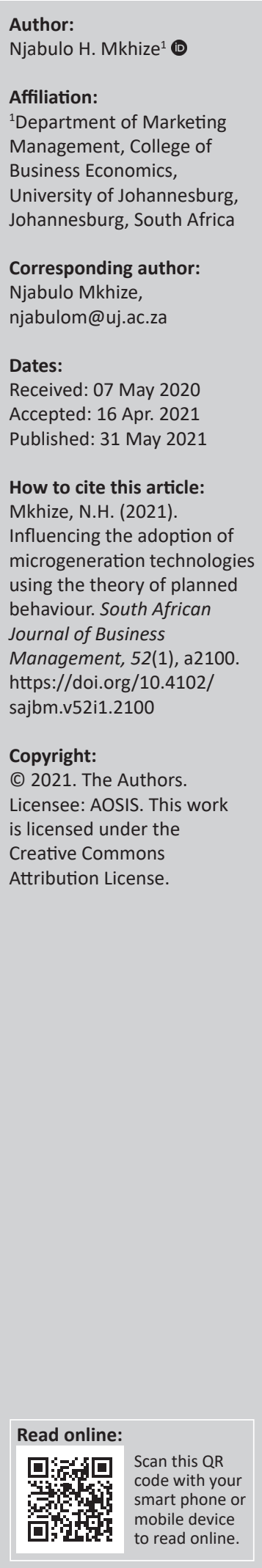

Purpose: This study sought to understand the factors that influence the behavioural intention of households towards microgeneration technologies. This includes subjective knowledge (SK) within the TPB framework as a determinant of behavioural intention.

Methods: A quantitative research approach was followed. A sample frame consisted of households as a unit. A structured questionnaire was administered by using convenience sampling approach. Respondents include members of households who were above the age of 18. Altogether, 237 usable self-administered questionnaires were used for the data.

Results: A two-stage procedure to perform Structural Equation Modeling (SEM) analysis by using SPSS AMOS 25 was conducted. The results showed that subjective norms (SNs) and attitude (ATT) had a significant and positive relationship with behavioural intention. Subjective knowledge showed no significant relationship.

Practical implications: Recommendations are made to marketers in relationship to cohesive message relating to microgeneration technologies with a special emphasis on reference groups in the messaging. For policymakers, there will be a need to consider the role of society and the immediate communities of potential adopters in their policy documents.

Originality/value: This study contributes to the scarce understanding of microgeneration technology in emerging markets by testing a proposed model by using data. It also enriches the adoption models via empirically exploring the relationship between SK and behavioural intention.

Keywords: microgeneration technologies; behavioural intention; attitude; subjective norm; subjective knowledge.

\section{Introduction}

The challenges of climate change have caused countries across the world to find solutions to decrease its spread; a key proposed change is increasing the supply of renewable energy (RE) technologies. Consequently, emerging countries such as South Africa have set targets to increase the adoption of RE technologies; these targets include having RE account for $26 \%$ of the total energy mix by 2030 (Minnock, 2018). India has similar targets, with their RE target aiming at 40\% (Institute for Energy Economics \& Financial Analysis, 2019), whilst China, whose contribution to carbon emission is known to be very high, is targeting 35\% of its total energy mix for RE (Lowder, 2018). Yet, these targets seem far-fetched, with RE technologies accounting for less than $5 \%$ of South Africa's energy mix. There are various sectors that could adopt RE technologies, with residents being one such sector.

Researchers have identified households as an important target population for the adoption of RE technologies - in the case of this study, microgeneration technologies (Baskaran, Managi, \& Bendig, 2013; Scarpa \& Willis, 2010). Naturally, residents account for a significant percentage of energy usage in their various activities, including electrification, heating and cooking. Globally, residents consume 20\% of the total energy (Karytsas, Vardopoulos, \& Theodoropoulou, 2019). For example, in South Africa, households account for $25 \%$ of the total energy consumption (Department of Energy, 2018), whilst China and India account for $12.4 \%$ and $24.3 \%$, respectively (Jiang, Chen, \& Xue, 2019; Singh, Mantha, \& Phalle, 2018). Given the reliance on coal-generated energy in emerging countries, there is a need to meet the different targets espoused by various emerging countries, and microgeneration technologies can also be effective in reducing environmental degradation. There is thus a need to define 'microgeneration technologies' or 'distributed generation technologies'; in this study they denote small-scale technologies that 
produce electricity and/or heat for household use (Grubic, Varga, Hu, \& Tewari, 2019; Karytsas et al., 2019).

A review of the literature suggests that plausible studies have sought to understand the behavioural antecedents of green purchasing behaviour (e.g. Emekci, 2019; Jaiswal \& Kant, 2018; Nguyen, Lobo, \& Nguyen, 2018). However, limited studies have pursued to investigate households adoption of microgeneration technologies, especially in emerging countries (Claudy, Peterson, \& O'Driscoll, 2013; Michelsen \& Madlener, 2013). In addition, knowledge is a prerequisite to adoption of any technology including microgeneration technologies (Claudy, Michelsen, O'Driscoll, \& Mullen, 2010). Understanding knowledge in the adoption of microgeneration technologies could provide significant findings. Although some studies have been conducted on households' adoption of microgeneration technologies in the context of developed countries, more studies need to be conducted in an emerging context. Primarily, households' size differs based on context, namely emerging and developed countries. For instance, the average household sizes in developed countries are below three members, whilst in emerging countries the average household size is above three and can rise to nine members per household in extreme cases (United Nations, 2017). This context provides grounds for a significant contribution as microgeneration technologies for households are highly dependent on household number.

Therefore, this study seeks to understand the factors that influence the behavioural intentions of households with regard to their adoption of microgeneration technologies, as informed by their affinity for green behaviour and captured by constructs of the model of the theory of planned behaviour (TPB). This study is therefore geared towards answering the following question: In the context of an emerging market such as that of South Africa, what are the psychological and sociological factors that influence consumers' behavioural intentions towards the adoption of the microgeneration technology of solar water heaters and solar panels?

The article is divided into four sections that lay the foundation to answering the research question. The first section comprises a literature review of the theory relating to microgeneration technology adoption; the antecedents that could possibly lead to their adoption are reviewed and form the basis for this study. This review is also underpinned by a discussion of the conceptual framework and the hypotheses. In the theoretical background section, the literature relating to electricity-saving behaviour and its associated determinants is reviewed, to form the foundation for the study. Following this, the research method section highlights key aspects, such as the data instrument and collection, the sampling method used and the constructs that form part of this study. A section on the presentation of the results is then outlined, focussing on a two-step analysis in which the measurement model results are discussed and the structural equation model results are presented. Lastly, the discussion and recommendations on the practical implications and future directions for research are proposed.

\section{Theoretical review}

The emphasis of this study is on the behaviour of households and does not discount factors such as financial resources, government support, lack of wide availability of microgeneration technologies that play an essential role in the adoption of microgeneration technologies specifically and environmental innovations in general. Theories and results from empirical studies are offered in this section, especially those relating to environmental innovation diffusion and adoption, to identify the various factors that influence this behaviour and the construction of the conceptual model.

Studies have sought to address the gap in empirical research into the attitude-behaviour gap amongst low-involvement products that are environmentally friendly on the part of households (Schäufele \& Hamm, 2018; Wiederhold \& Martinez, 2018). For instance, Schäufele and Hamm (2018) conducted research to understand the purchase of organic wine amongst consumers; Wiederhold and Martinez (2018) conducted an empirical study on green apparel; and Yamoah and Acquaye (2019) investigated attitude-behaviour gap with regard to the sustainable consumption of apples. They further validate the presence of the gap and reason that it is caused by purchase inhibitors.

The TPB (Ajzen, 1991) and the green consumer behaviour literature were found to be useful in understanding the intention in households, to purchase microgeneration technologies. This literature review section gives a brief overview of microgeneration technologies, and the TPB is outlined in relation to the adoption of environmentally friendly technologies, and specifically of microgeneration technologies and the related hypotheses, to provide a deeper understanding of green consumer behaviour in the context of households.

\section{Brief outline of microgeneration technologies}

'Residential microgeneration technologies' (or 'distributed generation technologies') denote small-scale technologies that produce electricity and/or heat for household use (Grubic et al., 2019; Karytsas et al., 2019). There are several different types of microgeneration technologies, including photovoltaic (PV) panels, micro-wind turbines, solar water heaters, wood pellet boilers, geothermal heat pumps and combined heat and power units (CHP) (Claudy, Michelsen, \& O'Driscoll, 2011). Microgeneration technology in the form of solar PV home installations is being fast adopted in many countries as a substitute for energy generation solutions that may be harmful to the environment (Qureshi, Ullah, \& Arentsen, 2017). This study focusses on solar water heaters and solar panels.

Studies indicate a need amongst developing countries for energy, whether the need is as desperate as having no energy or no stable energy supply (Schäfer, Kebir, \& Neumann, 2011). For instance, current statistics indicate that over 1.1 billion people are without electricity supply and many of whom are living in developing countries 
(Daly, 2018). Schäfer et al. (2011) add that the sub-Saharan Africa is the most affected region in terms of lack of energy supply and will continue to experience this phenomenon until 2030. The case for microgeneration technologies is heightened by this situation especially in developing countries. In addition to the lack of electricity, there are several other reasons, including their awareness of the impact of fossil-generated energy on the environment, the ongoing incremental increases in electricity tariffs by national energy suppliers (such as ESKOM in the case of South Africa) in developing countries and the inconsistency in energy supply from these national producers because of ageing infrastructure that can cause unplanned electricity outages, consumers are being encouraged to adopt microgeneration technologies.

Karytsas et al. (2019) defines these sorts of consumers as 'prosumers' (from producer and consumer), as they generate their own electricity and heat their own water. These prosumers are heeding the call from various stakeholders, such as environmental activists and governments, to be more environmentally sustainable by adopting innovations that are environmentally compatible (Shahsavar, Kubeš, \& Baran, 2019). Microgeneration technologies are those that are environmentally compatible, as they use renewable resources for energy generation.

The next section looks at the conceptual model and the hypotheses that relate to that model, which underpins the study.

\section{Conceptual framework}

The model underpinning this study is the TPB by Ajzen (1991) - see Figure 1. The model is an extension of the theory of reasoned action (TRA) by Fishbein and Ajzen (1975) and Fishbein (1980). The central theme in the TPB, as in the TRA, is that the behavioural intention of an individual leads to the performance of that behaviour (Ajzen, 1991).

The TPB was intended to predict and explain human behaviour in different contexts and seeks to understand the

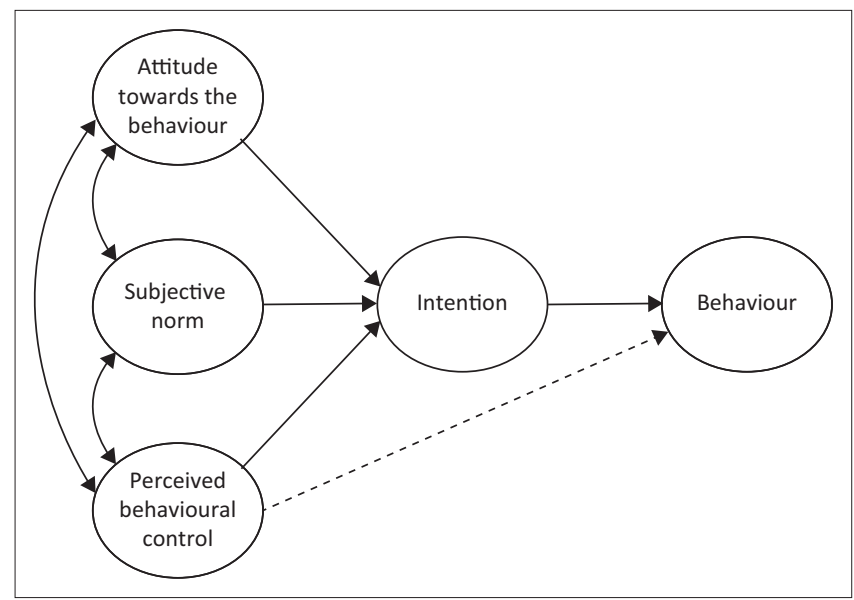

FIGURE 1: Theory of planned behaviour. relationship between an individual's attitudes (ATTs) and his or her actions (Ajzen, 1991, as cited in Hall, Turner, \& Kilpatrick, 2019). Furthermore, it is arguable that individuals' actions that are within their control and affected by their level of knowledge, their ATT and their desire to perform the action ultimately predict their behaviour (Hall et al., 2019). The consequences of behaviour (both negative and positive) are behavioural beliefs, that is the ATT towards a behaviour and the subjective norms (SNs) that relate to normative beliefs, and there are control beliefs, which this study does not investigate (Hall et al., 2019).

The next section discusses the determinants of behavioural intention - namely ATTs and SNs from the TPB model. Other determinants discussed include subjective knowledge (SK) and willingness to pay.

\section{Attitude}

'Attitude towards the behaviour (microgeneration technologies adoption)' refers to 'the degree to which a person has a favourable or unfavourable evaluation or appraisal of the behaviour in question' (Ajzen, 1991:188). Furthermore, ATT appreciates that the individual, as an actor, has the power to decide whether the behaviour (adoption of microgeneration technologies) is to be considered good or bad and whether they want to perform or act on that behaviour (Bazargan-Hejazi et al., 2017; Ham, Jeger, \& Ivković, 2015). According to Adnan, Nordin, Rahman and Rasli (2017), ATT is the positive or negative judgement of the behaviour being examined. Zailani, Iranmanesh, Masron and Chan (2016) stated that ATT determines human behaviour. The associated consequences of the behaviour play a significant role in ATT formation.

Ji and Chan (2019) find that the ATT towards energy saving leads to behavioural intention, and Islam (2014) explains ATT as a reaction of households towards microgeneration technologies. Hast, Alimohammadisagvand and Syri (2015) claims that, if a household's ATT towards microgeneration technologies is positive, there is a greater likelihood of the adoption of those technologies. Chen (2016) stated that, if households have environmentally friendly belief that installing microgeneration technologies will save the environment, their ATT towards such technologies is likely to be positive.

Wolske, Stern and Dietz (2017) finds that ATT is a predictor of the behavioural intention to use microgeneration technologies and that ATT has an impact on the intention to use them. Studies in the area of green consumption or green consumer behaviour have supported the relationship between ATT and behavioural intention; Taufique and Vaithianathan (2018) found support for this relationship when investigating general ecologically conscious consumption behaviour amongst Indian youth, whilst Lai and Cheng (2016) backed this relationship in their study, which investigated the role of green marketing practices in the willingness to purchase green products. 
The given literature review led to the formation of the following hypothesis:

H1: Attitude has a significant and positive influence on behavioural intention.

\section{Subjective norm}

In the TPB model, SNs are a determinant of behavioural intention. In defining 'SNs', Ajzen (1991:188) referred to them as 'the perceived social pressure to perform or not to perform the behaviour'. Put differently, Ham et al. (2015) referred to 'SN' as the belief that an important person or group of people will approve and support. The behaviour of an individual is affected by the social circles in which they live. Therefore, in this study, the adoption of microgeneration technologies is influenced by the friends, family and society in which householders reside. The more that people who are close to the individual intend to adopt microgeneration technologies, the greater the likelihood that the individual will adopt the behaviour. Subjective norm includes the individual's response to the pressure exerted by society (especially important members in one's society) to perform or not perform a behaviour.

Korcaj, Hahnel and Spada (2015) found that people might be reluctant to install microgeneration technologies if their reference group did not install them, to avoid disapproval or being rebuked. Wittenberg, Blöbaum and Matthies (2018) states that household owners may be motivated to install microgeneration technologies if they believe that others will approve of their behaviour and therefore SNs can impact the behavioural intention towards microgeneration technologies. If household owners are encouraged by family and friends to install microgeneration technologies, they are most likely to do so because they seek the approval of their family and friends, and they want to meet their expectations (Irfan, Zhao, Li \& Rehman 2020). According to Claudy, Michelsen and O'Driscoll (2017), the beliefs of friends and family about microgeneration technology can influence household owners' willingness to pay for such technology.

In marketing and consumer behaviour studies, the literature outlines the role that SNs play in influencing behavioural intention, including academic dishonesty (Kam, Hue, \& Cheung, 2018), recycling intention (Passafaro, Livi, \& Kosic, 2019), alcohol consumption (Cooke, Dahdah, Norman, \& French, 2016), predicting intention to consume green products (Hsu, Chang, \& Yansritakul, 2017; Paul, Modi, \& Patel, 2016; Yadav \& Pathak, 2016) and green purchasing behaviour (Liobikienè, Mandravickaite, \& Bernatonienė, 2016; Yadav \& Pathak, 2017). Studies within the area of energy saving and microgeneration technology (or RE technology) adoption showed that SNs are a determinant of behavioural intention (Abreu, Wingartz, \& Hardy, 2019; Chen, 2016; Gao, Wang, Li, $\& \mathrm{Li}, 2017)$. The review of the literature highlights the influence that SNs have on behavioural intention in different contexts. Therefore, a consumer's perception of their reference groups' endorsement or non-endorsement influences the individual purchase intention towards products or technologies, such as microgeneration technologies. It is therefore sensible to argue that social pressures have a significant role to play in the adoption of products such as microgeneration technologies and therefore we postulate that:

H2: Subjective norms positively influence households' behavioural intention to adopt microgeneration technologies.

\section{Subjective knowledge}

Consumer knowledge is an essential element in marketing practice and consumer behaviour theoretical models (Flynn \& Goldsmith, 1999). Consumer knowledge is arguably a key component in the buyer's decision-making process, especially in the information search stage of the process (Lee \& Koo, 2012). Studies acknowledge three categories of knowledge: objective, subjective and usage knowledge (Flynn \& Goldsmith, 1999; Lee \& Koo, 2012). According to Sangwan and Agarwal (2019), 'subjective knowledge' refers to 'the belief of consumers regarding their knowledge of the product'. In the case of this study, it is a household's knowledge of microgeneration technologies. Parkins, Rollins, Anders and Comeau (2018) states that SK can be explained as what households assume they know about microgeneration technologies. Therefore, SK deals with the confidence that individuals have in the knowledge that they have attained about a certain subject - in this case, knowledge related to microgeneration technologies. Subjective knowledge is also about the belief that an individual has in his or her knowledge. In measuring SK, studies use self-reporting in which customers highlight their knowledge of the product.

According to Aertsens, Mondelaers, Verbeke, Buysse and Van Huylenbroeck (2011), SK is regarded as a strong reason for behavioural intention. Wolske et al. (2017) states that households who come into contact with microgeneration technologies through friends or family members have increased knowledge about the cost of installing solar panels and the maintenance needed for microgeneration technologies. This also increases positive behavioural intention because households believe they are knowledgeable enough to install such technologies. Besides, Palm and Eriksson (2018) argues that households that have little or no knowledge about microgeneration technologies may be hesitant to adopt them; thus, having no knowledge about the cost and maintenance of microgeneration technologies may lead to a decrease in behavioural intention. Studies have shown the existence of a relationship between SK and other variables such as those proposed by Pieniak, Aertsens and Verbeke (2010), who studied SK as a determinant of organic vegetable consumption. In addition, Ahmad and Nordin (2014) studied students' SK of green computing and found that it is a determinant of behavioural intention. Given these influences from previous studies, it is expected that SK will have a similarly positive influence on an individual's behavioural intention to adopt microgeneration technologies:

H3: Subjective knowledge has a significant impact on behavioural intention.

The study proposes the following research framework. 


\section{Methodology}

The main objective of this study is to examine the psychological and sociological factors that influence consumers' behavioural intentions towards the adoption of the microgeneration technology. An empirical study was pursued to investigate the given research problem and objectives. A quantitative research method was followed in answering the research question, and the approach was cross-sectional in nature. The study used a self-administered questionnaire to collect data from respondents in the Gauteng province of South Africa. This form of data collection assists with reducing the response rate. The approach adopted in this study is similar to others adopted in answering similar research questions. For instance, Caird and Roy (2010) used self-administered questionnaires to investigate the adoption of microgeneration technologies in the United Kingdom, although they used multiple studies to understand the research question, but it is same design as this study. Another study was conducted by Claudy et al. (2011) who also used a survey design to test the willingness of houses to pay a premium for the adoption of microgeneration technologies. Therefore, this study is in line with other studies, which attempted to understand this type of research problem and empirically tested similar hypothesis.

\section{Sample size and composition}

Hair et al. (1998) suggested a desired level of 15-25 observations per studied variable to calculate a sample size required for a study. In the light of this calculation, this study consisted of four constructs with a combined total of 15 items which, when calculated, gave a desired sample of $225(15 \times 15)$. For structural equation modelling, it is generally argued that an adequate sample size for the SEM technique is anything more than 200 participants; however, this varies with the complexity of the model (Fan et al., 2016). The model for this study was simple, and so the decision was guided by the number of constructs, which was fewer than five. As a result of time and budget constraints, non-probability, convenience sampling method was utilised for this study. To meet the desired sample size, a total of 260 questionnaires were distributed but only 237 were usable for the analysis, as the balance were not returned or major parts of the questionnaires were empty or not adequately answered.

\section{Measures}

The research instrument used in this study was developed by using measures that had been tested and validated in previous studies. The research instrument, a survey, consisted of data that related to participants' demographical characteristics, ATT items, SNs items, SK items, diffusion of innovation constructs items (which did not form part of this study) and willingness to pay items. However, in this study we involved only those items that correspond to the TPB. A seven-point Likert scale was used (from $1=$ strongly agree to 7 = strongly disagree). The research instrument covered 23 questions on the topic of microgeneration technologies; however, only 15 items were used for the purpose of this study, more specifically looking at the adoption of solar panels and solar water heaters and different ATTs, SNs, SK and behavioural intention.

The five-item, seven-point Likert scale that was used to operationalise the ATT that households hold towards the adoption of microgeneration technologies was adopted from Ajzen (1991) and Claudy et al. (2011). The three-item, sevenpoint Likert scale that was used to measure SNs was also adopted from Ajzen (1991) and Claudy et al. (2011). Subjective knowledge consisted of three items, and the seven-point Likert scale used was adopted from Claudy et al. (2011). Furthermore, behavioural intention was operationalised with a four-item scale, also adapted from Ajzen (1991) and Claudy et al. (2011). A factor analysis, considering both dependent and independent variables, showed only four factors having more than 1 for their eigenvalues.

\section{Reliability of the scales}

A Cronbach's alpha was computed by using SPSS 24, and AMOS 25 was used to analyse the data set. As represented in Table 1, all items meet the threshold for factor loading and no items were deleted. A Cronbach's alpha test was run through SPSS 24, with all constructs meeting the minimum threshold of 0.7 (Kline, 2005). Behavioural intention had a Cronbach's alpha score of 0.856 , SNs had 0.747 , ATT had 0.874 and SK showed a score of 0.906 .

\section{Data analysis}

For the data analysis, the researchers used SPSS AMOS 25. The sample size requirements were for structural equation modelling to be conducted, as highlighted in the sub-section Sample size and composition in the Methodology section. A two-stage procedure was used to perform the SEM analysis. Firstly, the researchers examined the convergence and validity of the study's constructs by using the confirmatory factor analysis (CFA) and the reliability of their scales. The

\begin{tabular}{lcccccc} 
TABLE 1: Scale reliability. \\
\hline Variable & Item & Correlation & $\begin{array}{c}\text { Cronbach's } \\
\text { alpha }\end{array}$ & $\begin{array}{c}\text { Factor } \\
\text { loading }\end{array}$ & AVE & $\begin{array}{c}\text { Composite } \\
\text { reliability }\end{array}$ \\
\hline $\begin{array}{l}\text { Behavioural } \\
\text { intention }\end{array}$ & BI1 & 0.421 & 0.856 & 0.656 & 0.516 & 0.809 \\
& BI2 & 0.426 & - & 0.642 & - & - \\
& BI3 & 0.553 & - & 0.675 & - & - \\
& BI4 & 0.665 & - & 0.702 & - & - \\
Subjective & SN1 & 0.363 & 0.747 & 0.514 & 0.508 & 0.753 \\
norms & SN2 & 0.630 & - & 0.617 & - & - \\
& SN3 & 0.536 & - & 0.600 & - & - \\
Attitude & ATT1 & 0.538 & 0.874 & 0.564 & 0.591 & 0.877 \\
& ATT2 & 0.459 & - & 0.513 & - & - \\
& ATT3 & 0.768 & - & 0.598 & - & - \\
& ATT4 & 0.697 & - & 0.579 & - & - \\
& ATT5 & 0.489 & - & 0.645 & - & - \\
Subjective & SK1 & 0.598 & 0.906 & 0.682 & 0.743 & 0.896 \\
knowledge & SK2 & 0.814 & - & 0.674 & - & - \\
& SK3 & 0.818 & - & 0.655 & - & - \\
\hline
\end{tabular}

ATT, attitude, SN, subjective norms; SK, subjective knowledge; $\mathrm{BI}$, behavioural intention; AVE, average variance extracted. 
second stage dealts with the confirmation of the hypotheses of the study through SEM to test for possible causality in their relationships.

\section{Measurement model}

The conceptual model was studied by using CFA, which was analysed by using the maximum likelihood estimation. The four-factor model showed a good fit. All the items that were included in the model loaded with factors were above the recommended 0.5 (Chaudhary \& Bisai, 2018). The following results are shown in Table 3 and confirm that the measurement is a good fit: $\chi^{2}=144.990, d f=82, p=0.00$, Root Mean Square Error of Approximation (RMSEA) $=0.057$, Comparative Fit Index $(\mathrm{CFI})=0.97$, Normed Fit Index $(\mathrm{NFI})=0.93$ and $\chi^{2} / d f=1.76$. The $\chi^{2} / d f$ came close to the acceptable limit of between 2 and 5 . The model showed good fit for the statistics that met all the minimum thresholds recommended by previous studies (Chaudhary \& Bisai, 2018; Paul et al., 2016). Therefore, it can be concluded that the measurement items matched their underlying latent construct.

Table 2 shows the results that demonstrate discriminant validity. These results demonstrate that $\sqrt{ } A V E$ exceeded the squared correlations. All the AVE values were above 0.5 (Paul et al., 2016), and the composite construct reliability measures were all above the threshold of 0.7 , as shown in Table 1.

To test the causal relationships between the constructs and confirm the hypotheses that are outlined by this study, a structural equation model was used (Figure 3). The CFA makes available the opportunity to test the hypotheses. The results of the conceptual model showed a good fit with the data $\left(\chi^{2}=144.990, d f=82, p=0.00\right.$, RMSEA $=0.057, \mathrm{CFI}=0.97$,

TABLE 2: Discriminant validity.

\begin{tabular}{lcccc}
\hline Constructs & BI & SN & ATT & SK \\
\hline Behavioural intention & 0.719 & - & - & - \\
Subjective norms & 0.598 & 0.712 & - & - \\
Attitude & 0.442 & 0.339 & 0.769 & - \\
Subjective knowledge & 0.296 & 0.400 & 0.017 & 0.862 \\
\hline
\end{tabular}

Note: Diagonal values show the square root of each construct.

$\mathrm{BI}$, behavioural intention; SN, subjective norms; ATT, attitude; SK, subjective knowledge.

TABLE 3: Explanatory power and fit indices of models.

\begin{tabular}{lcc}
\hline Fit indices and $\boldsymbol{R}^{2}$ & Recommended value & Model \\
\hline$\chi^{2}$ & - & 144.990 \\
$d f$ & - & 82 \\
$\chi^{2} / d f$ & $2-5$ & 1.76 \\
$\mathrm{NFI}$ & $\geq 0.9$ & 0.93 \\
$\mathrm{CFI}$ & $\geq 0.9$ & 0.97 \\
$\mathrm{RMSEA}$ & $\leq 0.08$ & 0.057 \\
$R^{2}$ & - & - \\
$\mathrm{BI}$ & - & 0.43 \\
SN & - & 0.46 \\
Att & - & 0.28 \\
SK & - & 0.11 \\
\hline
\end{tabular}

$\mathrm{NFI}$, Normed Fit Index; CFI, Comparative Fit Index; RMSEA, Root Mean Square Error of Approximation; $\chi^{2}$, chi square; $d f$, degrees of freedom; $\mathrm{BI}$, behavioural intention SN, subjective norms; ATT, attitude; SK, subjective knowledge.
NFI $=0.93$ and $\left.\chi^{2} / d f=1.76\right)$. Therefore, it could be implied that the behavioural intentions of households towards microgeneration were well predicted by the conceptual model, although the explanatory power was very low (Table 3).

The paths illustrated by the standard coefficient estimates between ATT and behavioural intention $(\beta=0.284 ; p<0.001)$ and between SNs and behavioural intention $(\beta=0.459$; $p<0.0001$ ) were significant and positive, whilst that between SK and behavioural intention was not significant $(\beta=0.107$; $p>0.05$ ) (see Figure 2 and Table 4).

\section{Discussion and implications}

This study sought to answer the following research question: What are the psychological and sociological factors that influence consumers' behavioural intentions towards the adoption of the microgeneration technology of solar water heating and solar panels? It also sought to examine the applicability of the TPB in predicting the behavioural intention towards adopting microgeneration technologies amongst households in a developing country. This study adds to the limited body of literature in microgeneration adoption amongst households by using behavioural models (Claudy et al., 2011, 2013; Michelsen \& Madlener, 2013). The significant relationships were supported for the TPB constructs of SNs and ATT with behavioural intention, but no support was found for SK and behavioural intention. This implies that households' perceived knowledge of microgeneration technologies has no influence towards the adoption of these technologies. This result agrees with a study conducted in the financial services sector, in which customers' behavioural intention in saving for retirement did not show a significant relationship with SK (Rickwood, Johnson, Worthington, \& White, 2017). Yet, this goes contrary to the findings of other studies, which found

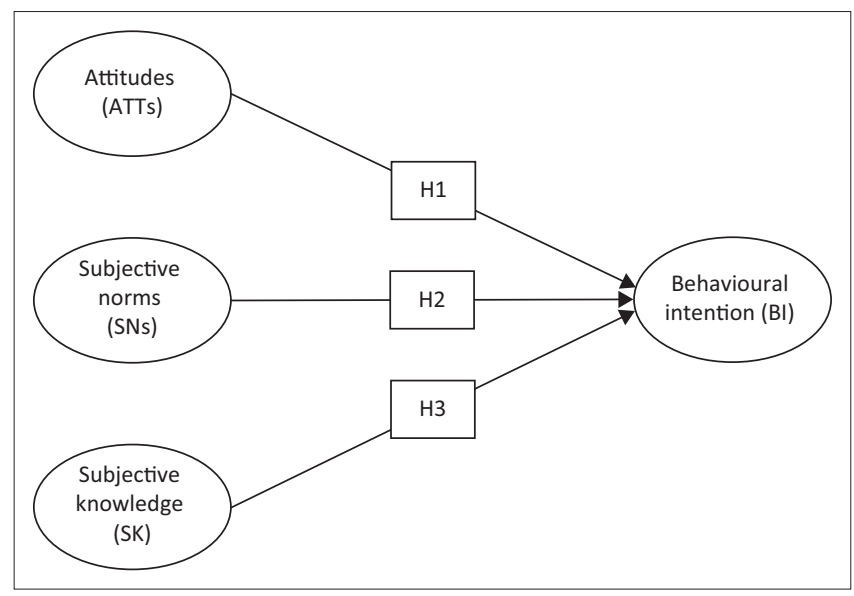

FIGURE 2: Proposed conceptual model.

TABLE 4: Hypotheses supported.

\begin{tabular}{lcl}
\hline Paths & Direct effect & Hypothesis support \\
\hline $\mathrm{BI} \leftarrow \mathrm{SN}$ & $0.459 *$ & Supported \\
$\mathrm{BI} \leftarrow \mathrm{ATT}$ & $0.284^{*}$ & Supported \\
$\mathrm{BI} \leftarrow$ SOLK & 0.107 & Rejected \\
\hline
\end{tabular}

$\mathrm{BI}$, behavioural intention; SN, subjective norms; ATT, attitude; SOLK, subjective knowledge. $*, p<0.001$. 


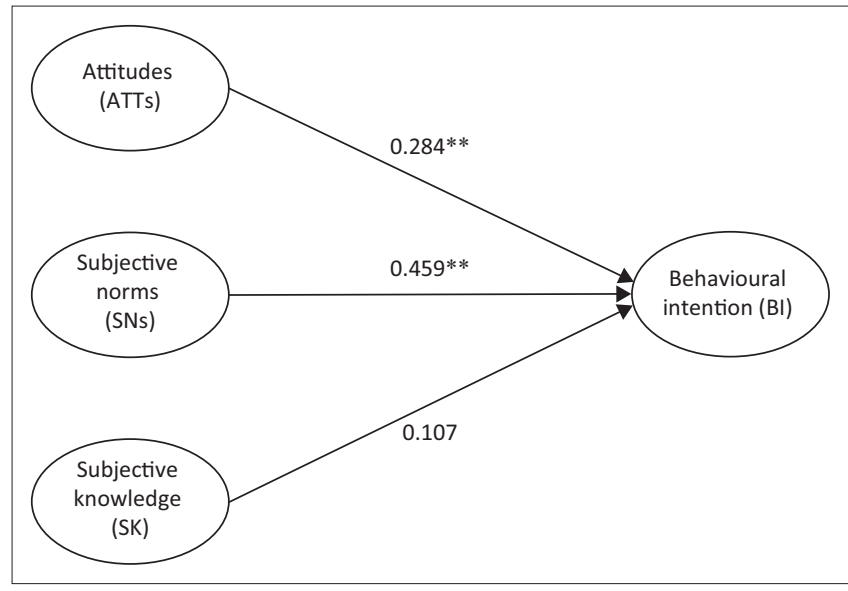

Source: Adapted from Ajzen, I. (1991). The theory of planned behavior. Organizational Behavior and Human Decision Processes, 50(2), 179-211. https://doi.org/10.1016/07495978(91)90020-T

FIGURE 3: Structural model.

SK to have a significant and positive relationship with behavioural intention (Ahmad \& Nordin, 2014; Pieniak et al., 2010). Rickwood et al. (2017) argued that the insignificant relationship could have been caused by individual respondents' self-belief and thus their belief was stronger than the SK. However, Ahmad and Nordin (2014) found that SK is a multidimensional construct and researchers should treat as such, which explain how their study had a significant relationship behaviour. This could be the difference between studies. In theory this implies that either the SK investigated in this study was not sufficient or that more items would need to be added to understand why SK has a significant relationship with behavioural intention.

This study found support for the relationship between SNs and behavioural intention. This could mean that the promotion of microgeneration technologies is reliant on reference groups, as households will look to close friends and family to adopt this behaviour. This is reasonable, as studies show that SNs have a significant and positive relationship with behavioural intention (Abreu et al., 2019; Chen, 2016; Gao et al., 2017). Therefore, households are guided by the perception of endorsement, or the lack thereof, from their reference groups. Furthermore, the SN to behavioural intention relationship was the strongest, based on the standardised coefficient. This implies that marketers of microgeneration technologies should use the adoption by reference groups of households to convince or drive the message of these technologies amongst households. For policymakers, there will be a need to consider the role of society and the immediate communities of potential adopters in their policy documents, as consumers' perception of their reference groups' endorsement (or non-endorsement) influences the individual's purchase intention towards microgeneration technologies.

\section{Limitations and directions for future research}

No study is without its limitations, and our study is no exception. A self-administered instrument opens individuals to the influence of either understating or overstating their behaviour, either to appease their conscience or to fit in with the society or close group of friends (Hulland, Baumgartner, \& Smith, 2018). This is a major limitation for most studies that use self-reporting as the form of data collection (Hulland et al., 2018). Future research could consider other ways of collecting data, such as experiments or case studies, in which there is a reduced common method bias. Furthermore, the sampling method used, convenience sampling, opened this study to the limitation of finding respondents at the convenience of the researchers, and so it could lead to a selection of respondents that was not suitable for the study. In future studies, it will be commendable for such a study to use stratified sampling. As a result of time constraints, the study was cross-sectional in nature, which limited the researcher's ability to imply causality in the relationships tested in this study. A longitudinal research design could be carried out in future studies. It is further recommended that future studies have a screening question that relates to whether the respondents own or rent the house in which they live and whether it is a stand-alone dwelling or a flat, as that has an impact on the installation of microgeneration technologies.

\section{Conclusion}

This study assists in contributing to insights into the role of the psychological and sociological factors that influence behavioural intention towards microgeneration technologies in developing countries. The study enhances extant knowledge in the determinants of microgeneration technology adoption by households in developing countries. In considering the results of this study, developing countries should understand the role that the psychological and sociological factors play in influencing behavioural intention towards microgeneration technologies to curb the lack of electricity and consequently the degradation of the environment caused by fossil fuel-based electricity generation.

\section{Acknowledgements}

The author would like to acknowledge UJ BCOM honours group research project where he was designated as a supervisor.

\section{Competing interests}

N.H.M. has declared that no competing interests exist.

\section{Author's contributions}

N.H.M. declares that he is the sole author of this research article.

\section{Ethical considerations}

Ethical permission for this study was obtained from the CiiS Ethics Committee (No.: 2018MM011).

\section{Funding information}

This research received no specific grant from any funding agency in the public, commercial or not-for-profit sectors. 


\section{Data availability}

The author confirms that the data supporting the findings of this study are available within the article.

\section{Disclaimer}

The views and opinions expressed in this article are those of the author and do not necessarily reflect the official policy or position of any affiliated agency of the author.

\section{References}

Abreu, J., Wingartz, N., \& Hardy, N. (2019). New trends in solar: A comparative study assessing the attitudes towards the adoption of rooftop PV. Energy Policy, 128, 347-363. https://doi.org/10.1016/j.enpol.2018.12.038

Adnan, N., Nordin, S.M., Rahman, I., \& Rasli, A.M. (2017). A new era of sustainable transport: An experimental examination on forecasting adoption behavior of EVs among Malaysian consumer. Transportation Research Part A: Policy and Practice, 103, 279-295. https://doi.org/10.1016/j.tra.2017.06.010

Aertsens, J., Mondelaers, K., Verbeke, W., Buysse, J., \& Van Huylenbroeck, G. (2011). The influence of subjective and objective knowledge on attitude, motivations and consumption of organic food. British Food Journal, 113(11), 1353-1378. https:// doi.org/10.1108/00070701111179988

Ahmad, T.B.T., \& Nordin, M.S. (2014). University students' subjective knowledge of green computing and pro-environmental behavior. International Education Studies, 7(2), 64-74. https://doi.org/10.5539/ies.v7n2p64

Ajzen, I. (1991). The theory of planned behavior. Organizational Behavior and Human Decision Processes, 50(2), 179-211. https://doi.org/10.1016/0749 5978(91)90020-T

Baskaran, R., Managi, S., \& Bendig, M. (2013). A public perspective on the adoption of microgeneration technologies in New Zealand: A multivariate probit approach. Energy Policy, 58, 177-188. https://doi.org/10.1016/j.enpol.2013.02.047

Bazargan-Hejazi, S., Teruya, S., Pan, D., Lin, J., Gordon, D., Krochalk, P.C., \& Bazargan, M. (2017). The theory of planned behavior (TPB) and texting while driving behavior in college students. Traffic Injury Prevention, 18(1), 56-62. https://doi.or $\mathrm{g} / 10.1080 / 15389588.2016 .1172703$

Caird, S., \& Roy, R., 2010. Adoption and use of household microgeneration heat technologies. Low Carbon Economy, 1(2), 61-70. https://doi.org/10.4236/ Ice.2010.12008

Chaudhary, R., \& Bisai, S. (2018). Factors influencing green purchase behavior of millennials in India. Management of Environmental Quality: An International Journal, 29(5), 798-812. https://doi.org/10.1108/MEQ-02-2018-0023

Chen, M.F. (2016). Extending the theory of planned behavior model to explain people's energy savings and carbon reduction behavioral intentions to mitigate climate change in Taiwan-moral obligation matters. Journal of Cleaner Production, 112, 1746-1753. https://doi.org/10.1016/j.jclepro.2015.07.043

Claudy, M.C., Michelsen, C., \& O'Driscoll, A. (2011). The diffusion of microgeneration technologies-assessing the influence of perceived product characteristics on home owners' willingness to pay. Energy Policy, 39(3), 1459-1469. https://doi. org/10.1016/j.enpol.2010.12.018

Claudy, M.C., Michelsen, C., O'Driscoll, A., \& Mullen, M.R. (2010). Consumer awareness in the adoption of microgeneration technologies: An empirical investigation in the Republic of Ireland. Renewable and Sustainable Energy Reviews, 14(7), 2154-2160. https://doi.org/10.1016/j.rser.2010.03.028

Claudy, M.C., Peterson, M., \& O'Driscoll, A. (2013). Understanding the attitudebehavior gap for renewable energy systems using behavioral reasoning theory. Journal of Macromarketing, 33(4), 273-287. https://doi.org/10.1177/027614 6713481605

Cooke, R., Dahdah, M., Norman, P., \& French, D.P. (2016). How well does the theory of planned behaviour predict alcohol consumption? A systematic review and metaanalysis. Health Psychology Review, 10(2), 148-167. https://doi.org/10.1080/174 37199.2014.947547

Daly, H. (2018). 1.1 billion people still lack electricity. This could be the solution. World Economic Forum. Retrieved from https://www.weforum.org/agenda/2018/06/1 billion-people-lack-electricity-solution-mini-grid-iea/

Department of Energy. (2018). South African energy sector report. Retrieved from http://www.energy.gov.za/files/media/explained/2018-South-African-EnergySector-Report.pdf

Emekci, S. (2019). Green consumption behaviours of consumers within the scope of TPB. Journal of Consumer Marketing, 36(3), 410-417. https://doi.org/10.1108/ JCM-05-2018-2694

Fan, Y., Chen, J., Shirkey, G., John, R., Wu, S.R., Park, H., \& Shao, C. (2016). Applications of structural equation modeling (SEM) in ecological studies: An updated review. Ecological Processes, 5(1), 19. https://doi.org/10.1186/s13717-016-0063-3

Fishbein, M. (1980). A theory of reasoned action: Some applications and implications. In: H. Howe \& M. Page (Eds.), Nebraska symposium on motivation (Vol. 27, pp. 65-116). Lincoln: University of Nebraska Press.

Fishbein, M., \& Ajzen, I. (1975). Belief, attitude, intention and behavior: An introduction to theory and research. Reading, MA: Addison-Wesley.
Flynn, L.R., \& Goldsmith, R.E. (1999). A short, reliable measure of subjective knowledge. Journal of Business Research, 46(1), 57-66. https://doi.org/10.1016/ S0148-2963(98)00057-5

Gao, L., Wang, S., Li, J., \& Li, H. (2017). Application of the extended theory of planned behavior to understand individual's energy saving behavior in workplaces. Resources, Conservation and Recycling, 127, 107-113. https://doi.org/10.1016/j. resconrec.2017.08.030

Grubic, T., Varga, L., Hu, Y., \& Tewari, A. (2019). Micro-generation technologies and consumption of resources: A complex systems' exploration. Journal of Cleaner Production, 247, 119091. https://doi.org/10.1016/j.jclepro.2019.119091

Hair, J.F., Black, W.C., Babin, B.J., Anderson, R.E., \& Tatham, R.L., 1998. Multivariate data analysis (Vol. 5, No. 3, pp. 207-219). Upper Saddle River, NJ: Prentice Hall.

Hall, A., Turner, L., \& Kilpatrick, S. (2019). Using the theory of planned behaviour framework to understand Tasmanian dairy farmer engagement with extension activities to inform future delivery. The Journal of Agricultural Education and Extension, 25(3), 195-210. https://doi.org/10.1080/1389224X.2019.1571422

Ham, M., Jeger, M., \& Ivković, A.F. (2015), The role of subjective norms in forming the intention to purchase green food. Economic Research-Ekonomska Istraživanja 28(1), 738-748. https://doi.org/10.1080/1331677X.2015.1083875

Hast, A., Alimohammadisagvand, B., \& Syri, S. (2015). Consumer attitudes towards renewable energy in China: The case of Shanghai. Sustainable Cities and Society, 17, 69-79.

Hsu, C.L., Chang, C.Y., \& Yansritakul, C. (2017). Exploring purchase intention of green skincare products using the theory of planned behavior: Testing the moderating effects of country of origin and price sensitivity. Journal of Retailing and Consumer Services, 34, 145-152. https://doi.org/10.1016/j.jretconser.2016.10.006

Hulland, J., Baumgartner, H., \& Smith, K.M. (2018). Marketing survey research best practices: Evidence and recommendations from a review of JAMS articles. Journal of the Academy of Marketing Science, 46(1), 92-108. https://doi.org/10.1007/ s11747-017-0532-y

Institute for Energy Economics \& Financial Analysis, 2019, India ups renewable energy target to 500GW by 2030, Institute for Energy Economics \& Financial Analysis, viewed 01 May 2020, from https://ieefa.org/india-ups-renewable-energy-targetto-500gw-by-2030/

Irfan, M, Zhao, ZY, Li, H. \& Rehman, A. (2020). The influence of consumers intention factors on willingness to pay for renewable energy: A structural equation modeling approach. Environmental Science and Pollution Research, 27(17), 21747-21761.

Islam, T. (2014). Household level innovation diffusion model of photo-voltaic (PV) solar cells from stated preference data. Energy Policy, 65, 340-350.

Jaiswal, D., \& Kant, R. (2018). Green purchasing behaviour: A conceptual framework and empirical investigation of Indian consumers. Journal of Retailing and Consumer Services, 41, 60-69. https://doi.org/10.1016/j.jretconser.2017. Consumer
11.008

Ji, W. \& Chan, E.H. (2019). Critical factors influencing the adoption of smart home energy technology in China: A Guangdong province case study. Energies, 12(21), 4180. https://doi.org/10.3390/en12214180

Jiang, L., Chen, X., \& Xue, B. (2019). Features, driving forces and transition of the household energy consumption in China: A review. Sustainability, 11(4), 1186. https://doi.org/10.3390/su11041186

Kam, C.C.S., Hue, M.T., \& Cheung, H.Y. (2018). Academic dishonesty among Hong Kong secondary school students: Application of theory of planned behaviour. Educational Psychology, 38(7), 945-963. https://doi.org/10.1080/01443410.2018. 1454588

Karytsas, S., Vardopoulos, I., \& Theodoropoulou, E. (2019). Factors affecting sustainable market acceptance of residential microgeneration technologies. A two time period comparative analysis. Energies, 12(17), 3298-3318. https://doi. org/10.3390/en12173298

Kline, R.B. (2005). Principles and practice of structural equation modelling (2nd edn.). New York, NY: The Guilford Press.

Korcaj, L., Hahnel, U.J., \& Spada, H. (2015). Intentions to adopt photovoltaic systems depend on homeowners' expected personal gains and behavior of peers. Renewable Energy, 75, 407-415.

Lai, C.K., \& Cheng, E.W. (2016). Green purchase behavior of undergraduate students in Hong Kong. The Social Science Journal, 53(1), 67-76. https://doi.org/10.1016/j. soscij.2015.11.003

Lee, K.T., \& Koo, D.M. (2012). Effects of attribute and valence of e-WOM on message adoption: Moderating roles of subjective knowledge and regulatory focus Computers in Human Behavior, 28(5), 1974-1984. https://doi.org/10.1016/j. chb.2012.05.018

Liobikienè, G., Mandravickaitè, J., \& Bernatonienè, J. (2016). Theory of planned behavior approach to understand the green purchasing behavior in the EU: A cross-cultural study. Ecological Economics, 125, 38-46. https://doi.org/10.1016/j. ecolecon.2016.02.008

Lowder, K. (2018). China proposes $75 \%$ increase to 2030 renewable energy target. CleanTechnica. Retrieved from https://cleantechnica.com/2018/09/27/chinaproposes-75-increase-to-2030-renewable-energy-target/

Michelsen, C.C., \& Madlener, R. (2013). Motivational factors influencing the homeowners' decisions between residential heating systems: An empirical analysis for Germany. Energy Policy, 57, 221-233. https://doi.org/10.1016/j. enpol.2013.01.045

Minnock, O. (2018). South Africa announces 2030 renewable energy goals. Energydigital.com. Retrieved from https://www.energydigital.com/renewableenergy/south-africa-announces-2030-renewable-energy-goals 
Nguyen, T.N., Lobo, A., \& Nguyen, B.K. (2018). Young consumers' green purchase behaviour in an emerging market. Journal of Strategic Marketing, 26(7), 583-600. https://doi.org/10.1080/0965254X.2017.1318946

Palm, J., \& Eriksson, E. (2018). Residential solar electricity adoption: How households in Sweden search for and use information. Energy, Sustainability and Society, 8(1), 1-9.

Parkins, J.R., Rollins, C., Anders, S., \& Comeau, L. (2018). Predicting intention to adopt solar technology in Canada: The role of knowledge, public engagement, and visibility. Energy Policy, 114, 114-122.

Passafaro, P., Livi, S., \& Kosic, A. (2019). Local norms and the theory of planned behaviour: Understanding the effects of spatial proximity on recycling intention and self-reported ecological behaviour. Frontiers in Psychology, 10, 744. https:// doi.org/10.3389/fpsyg.2019.00744

Paul, J., Modi, A., \& Patel, J. (2016). Predicting green product consumption using theory of planned behavior and reasoned action. Journal of Retailing and ConsumerServices, 29,123-134. https://doi.org/10.1016/j.jretconser.2015.11.006

Pieniak, Z., Aertsens, J., \& Verbeke, W. (2010). Subjective and objective knowledge as determinants of organic vegetables consumption. Food Quality and Preference, 21(6), 581-588. https://doi.org/10.1016/j.foodqual.2010.03.004

Qureshi, T.M., Ullah, K., \& Arentsen, M.J. (2017). Factors responsible for solar PV adoption at household level: A case of Lahore, Pakistan. Renewable and Sustainable Energy Reviews, 78, 754-763. https://doi.org/10.1016/j.rser.2017.04.020

Rickwood, C.M., Johnson, L.W., Worthington, S., \& White, L. (2017). Customer intention to save for retirement using a professional financial services planner. Financial Planning Research Journal, 3(2), 47-67.

Sangwan, S., \& Agarwal, P. (2019). Effect of consumer self-confidence on information search and dissemination: Mediating role of subjective knowledge. Internationa Journal of Consumer Studies, 43(1), 46-57. https://doi.org/10.1111/ijcs.12482

Scarpa, R., \& Willis, K. (2010). Willingness-to-pay for renewable energy: Primary and discretionary choice of British households' for micro-generation technologies. Energy Economics, 32(1), 129-136. https://doi.org/10.1016/j.eneco.2009.06.004

Schäfer, M., Kebir, N. and Neumann, K., 2011. Research needs for meeting the challenge of decentralized energy supply in developing countries. Energy for Sustainable Development, 15(3), 324-329. https://doi.org/10.1016/j.esd.2011.07.001

Schäufele, I., \& Hamm, U. (2018). Organic wine purchase behaviour in Germany: Exploring the attitude-behaviour-gap with data from a household panel. Food Quality and Preference, 63,1-11. https://doi.org/10.1016/j.foodqual.2017.07.010
Shahsavar, T., Kubeš, V., \& Baran, D. (2019). Willingness to pay for eco-friendly furniture based on demographic factors. Journal of Cleaner Production, 250, 119466. https://doi.org/10.1016/j.jclepro.2019.119466

Singh, J., Mantha, S.S., \& Phalle, V.M. (2018). Characterizing domestic electricity consumption in the Indian urban household sector. Energy and Buildings, 170 74-82. https://doi.org/10.1016/j.enbuild.2018.04.002

Taufique, K.M.R., \& Vaithianathan, S. (2018). A fresh look at understanding Green consumer behavior among young urban Indian consumers through the lens of Theory of Planned Behavior. Journal of Cleaner Production, 183, 46-55. https:// doi.org/10.1016/j.jclepro.2018.02.097

United Nations. (2017). Population facts. Retrieved from https://www.un.org/en/ development/desa/population/publications/pdf/popfacts/PopFacts_2017-2.pdf

Wiederhold, M., \& Martinez, L.F. (2018). Ethical consumer behaviour in Germany: The attitude-behaviour gap in the green apparel industry. International Journal of Consumer Studies, 42(4), 419-429. https://doi.org/10.1111/ijcs.12435

Wittenberg, I., Blöbaum, A., \& Matthies, E., (2018). Environmental motivations for energy use in PV households: Proposal of a modified norm activation model for the specific context of PV households. Journal of Environmental Psychology, 55, 110-120.

Wolske, K.S., Stern, P.C., \& Dietz, T. (2017). Explaining interest in adopting residential solar photovoltaic systems in the United States: Toward an integration of behavioral theories. Energy Research \& Social Science, 25, 134-151.

Yadav, R., \& Pathak, G.S. (2016). Young consumers' intention towards buying green products in a developing nation: Extending the theory of planned behavior Journal of Cleaner Production, 135, 732-739. https://doi.org/10.1016/j. jclepro.2016.06.120

Yadav, R., \& Pathak, G.S. (2017). Determinants of consumers' green purchase behavior in a developing nation: Applying and extending the theory of planned behavior. Ecological Economics, 134, 114-122. https://doi.org/10.1016/j. ecolecon.2016.12.019

Yamoah, F.A., \& Acquaye, A. (2019). Unravelling the attitude-behaviour gap paradox for sustainable food consumption: Insight from the UK apple market. Journal of Cleaner Production, 217, 172-184. https://doi.org/10.1016/j.jclepro.2019.01.094

Zailani, S, Iranmanesh, M. Masron, T.A., \& Chan, T.H. (2016). Is the intention to use public transport for different travel purposes determined by different factors? Transportation Research Part D: Transport and Environment, 49, 18-24. https:// doi.org/10.1016/j.trd.2016.08.038 